\title{
Involvement of Epstein-Barr virus latent membrane protein 1 in disease progression in patients with idiopathic pulmonary fibrosis
}

\author{
K Tsukamoto, H Hayakawa, A Sato, K Chida, H Nakamura, K Miura
}

\begin{abstract}
Background-The role of Epstein-Barr virus (EBV) in idiopathic pulmonary fibrosis (IPF) is uncertain. A study was undertaken to detect the virus in IPF as well as to clarify the influence of $\mathrm{EBV}$ on the clinical features of the disease.

Methods-Twenty nine lung specimens were obtained from patients with IPF, as well as five specimens from patients with systemic sclerosis with pulmonary fibrosis (SSc) and 15 specimens from controls. EBV DNA and EBV latent membrane protein 1 (LMP1) were detected using the PCR method and immunohistochemical analysis, respectively.

Results-EBV DNA was detected in 24 of 25 patients with IPF $(96 \%)$, in all five patients with SSc (100\%), and in 10 of 14 controls $(71 \%)$. The detection ratio was significantly higher in patients with IPF than in controls ( $p=0.047$, odds ratio $(\mathrm{OR})=9.60,95 \%$ confidence interval $(\mathrm{CI})$ 0.9 to 96.9$)$. Immunohistochemical analysis revealed that cuboidal epithelial cells were positively stained with anti-LMP1 antibody in nine of the 29 lung specimens from IPF patients. In contrast, neither the patients with SSc nor the control subjects showed positive staining. In the follow up periods LMP1 positive patients with IPF died more frequently from respiratory failure than LMP1 negative patients (4/9 versus $1 / 20 ; p=0.022, \mathrm{OR}=15.20,95 \% \mathrm{CI}$ 1.3 to 168.0$)$.

Conclusions-EBV LMP1 positivity may be associated with more rapid disease progression in IPF.

(Thorax 2000;55:958-961)
\end{abstract}

Keywords: idiopathic pulmonary fibrosis; Epstein-Barr virus; latent membrane protein 1 (LMP1)

Idiopathic pulmonary fibrosis (IPF)/ cryptogenic fibrosing alveolitis (CFA) is a chronic inflammatory disease with a poor prognosis. About half of the patients die of respiratory failure within five years. ${ }^{12}$ Although the aetiology of IPF remains unclear, serological studies of patients with IPF have suggested a possible role for the Epstein-Barr virus (EBV). ${ }^{3}$ In addition, as a result of an immunohistochemical study using monoclonal antibodies against EBV viral antigen, VCA and gp $340 / 220$, Egan et $a l^{4}$ have recently suggested that EBV replicates in the pulmonary epithelial cells of some IPF patients. Controversy exists as to whether EBV DNA can be detected in the lungs of patients with IPF; Stewart et $a \bar{l}$ detected EBV DNA in the lungs of patients with IPF significantly more frequently than in those of normal controls whereas Wangoo et $a l^{6}$ failed to detect EBV DNA in the lungs of patients with IPF. In the present study we have used polymerase chain reaction (PCR) to detect EBV DNA in the lungs of these patients.

Latent membrane protein 1 (LMP1) is one of the EBV associated proteins and is expressed on the surface of EBV infected cells in the latent and replicating phases. ${ }^{78}$ Much attention has been paid to LMP1 because various functions have been revealed in recent decades. For example, LMP1 is essential for the in vitro transformation of human lymphocytes ${ }^{9}$ and rodent fibroblasts ${ }^{10}$ by EBV. It has also been reported that LMP1 influences the differentiation, morphology, and growth of human epithelial cell lines. ${ }^{11} 12$ Thus, it is possible that cells expressing LMP1 in the lungs may modulate the chronic inflammatory process in some pulmonary diseases. Here we present data which indicate that patients with IPF with positive staining for LMP1 have more progressive disease than LMP1 negative patients.

\section{Methods}

PATIENTS

Twenty nine patients with IPF (22 men) of mean age 58 years (range 38-72) were included in the study. The diagnosis of IPF was based on accepted criteria $^{2}$ which included clinical dyspnoea on exertion, cough, clubbing and bibasal crackles, radiological evidence of diffuse parenchymal infiltrates (peripheral reticulonodular pattern with a lower lobe predominance), compatible high resolution CT appearance, ${ }^{13}$ and physiologically restrictive lung function. All patients underwent open lung or videothoracoscopic lung biopsy and were histologically diagnosed as having usual interstitial pneumonia (UIP). None were receiving medications such as steroids or immunosuppressive agents at the time of the study. Twenty one of the 29 patients were smokers and 18 had clubbing. The severity of the dyspnoea and chest radiographic abnormality at the initial examination was graded according to a score reported previously. ${ }^{14}$

Five patients with systemic sclerosis (SSc) with pulmonary fibrosis who fulfilled the American Rheumatism Association preliminary criteria for the diagnosis of $\mathrm{Ssc}^{15}$ were also included in the study. They consisted of three men and two women of mean age 54 years 
(range 44-62). All patients underwent open lung or videothoracoscopic lung biopsy to investigate their pulmonary disease.

All patients were followed up every month to investigate disease progression. The mean follow up period from the initial examination was 41 months (range 3-105) in patients with IPF and 54 months (range 15-94) in those with SSc. There was no significant difference in the follow up period between the two groups of patients.

As controls, tissue was taken from unaffected regions of lungs resected form 15 patients with primary lung tumours (nine patients) or bullae (six patients).

TISSUE PREPARATION

Lung tissue was fixed in 15\% formaldehyde immediately after resection, then dehydrated and embedded in paraffin. Six sections $(10 \mu \mathrm{m}$ thick) from each block were collected in a single tube for PCR analysis. For immunohistochemical analysis $3 \mu \mathrm{m}$ sections were placed onto glass slides pretreated with 3-aminopropyltriethoxysilane.

POLYMERASE CHAIN REACTION

The lung tissues were digested with proteinase $\mathrm{K}(0.2 \mathrm{mg} / \mathrm{ml})$ and DNA was extracted using phenol/chloroform.

The PCR for EBV DNA was performed according to the method of Hashimoto et $a l^{16}$ with some modifications. Briefly, the PCR mixture contained $1 \mu \mathrm{g}$ DNA, $5 \mu$ of $10 \times$ Taq polymerase buffer (100 mM Tris- $\mathrm{HCl}$, $\mathrm{pH} 8.8,500 \mathrm{mM} \mathrm{KCl}, 15 \mathrm{mM} \mathrm{MgCl}$, and $1 \%$ Triton X-100), $200 \mu \mathrm{mol} / 1$ of each deoxynucleotide, $25 \mathrm{pmol}$ of EBV primers (5'CACTTTAGAGCTCTGGAGGA-3' and 5'-TAAAGATAGCAGCAGCGCAG-3'), and 1.25 units of Taq polymerase (Nippon Gene Co Ltd, Tokyo, Japan) in a final volume of $50 \mu$ l. After initial incubation for three minutes at $94^{\circ} \mathrm{C}, 40 \mathrm{PCR}$ cycles were performed which involved denaturing at $94^{\circ} \mathrm{C}$ for one minute, annealing at $57^{\circ} \mathrm{C}$ for 0.5 minute, and extension at $72^{\circ} \mathrm{C}$ for 1.5 minute. The amplified product was $153 \mathrm{bp}$ in size. One $\mu \mathrm{l}$ of the first PCR product was subjected to the second PCR with a different primer set (5'AACTTTAGAGGCGAATGGGC-3' and 5'TAAAGATAGCAGCAGCGCAG-3'). The amplified product was $112 \mathrm{bp}$ in size.

The PCR for $\beta$-globin was performed by the same procedure but with a different primer set (5'-GAAGAGCCAAGGACAGGTAC-3' and 5'-CAACTTCATCCACGTTCACC- $\left.3^{\prime}\right)^{17}$ and some differences in the cycles (initial incubation for five minutes at $95^{\circ} \mathrm{C}$ followed by 35 cycles of denaturing at $95^{\circ} \mathrm{C}$ for 50 seconds, annealing at $56^{\circ} \mathrm{C}$ for 50 seconds, and extension at $72^{\circ} \mathrm{C}$ for 70 seconds).

PCRs performed with DNA extracted from EBV infected tissues and DNA amplified without a template were used as the positive and negative controls, respectively. The PCR products of EBV DNA were confirmed to be the expected sequences by restriction fragment length polymorphism analysis.
Table 1 Frequency of detection of EBV DNA in the lungs by PCR

\begin{tabular}{ll} 
IPF patients & $24 / 25(96 \%)^{\star}$ \\
SSc patients & $5 / 5(100 \%)$ \\
Normal controls & $10 / 14(71 \%)$ \\
\hline
\end{tabular}

$\mathrm{IPF}=$ idiopathic pulmonary fibrosis; $\mathrm{SSc}=$ systemic sclerosis. ${ }^{\star} \mathrm{p}<0.05$.

IMMUNOHISTOCHEMICAL ANALYSIS

Immunohistochemical analysis was performed using the streptavidin-biotin method with a SAB-PO kit (Nichirei Co Ltd, Tokyo, Japan). Anti-LMP1 monoclonal antibody (Dakopatts, Copenhagen, Denmark) was used at a dilution of $1: 100$. The antibody was detected with 3,3'diaminobenzidine tetrahydrochloride and the specimens were counterstained with methyl green (Merck, Darmstadt, Germany).

For immunohistochemical controls, normal mouse immunoglobulin $\mathrm{G}$ was used as the first antibody. LMP1 positivity was evaluated by two observers $(\mathrm{KT}, \mathrm{HH})$ without knowledge of clinical data and there were no interobserver differences.

STATISTICAL ANALYSIS

Differences in frequency were assessed using Fisher's exact probability test, and the MannWhitney U test was used to compare quantitative data between the groups. A p value of $<0.05$ was considered to indicate statistical significance.

\section{Results}

DETECTION OF EBV DNA IN LUNG TISSUES BY PCR $\beta$-globin DNA was amplified in 25 of the 29 patients with IPF $(86 \%)$, in all five of the patients with SSc $(100 \%)$, and in 14 of the 15 controls (93\%). Detection of EBV DNA was examined in the $\beta$-globin DNA positive cases.

EBV DNA was found in 24 of 25 patients with IPF (96\%), in all five of the patients with SSc $(100 \%)$, and in 10 of 14 controls $(71 \%)$, indicating that EBV DNA was detected more frequently in the lungs of IPF patients than in controls $(\mathrm{p}=0.047$, odds ratio $(\mathrm{OR})=9.60$, $95 \%$ confidence interval (CI) 0.9 to 96.9 ), table 1 .

IMMUNOHISTOCHEMICAL ANALYSIS

Cuboidal lung epithelial cells were positively stained for LMP1 in nine of the 29 patients with IPF $(31 \%)$. A representative example is shown in fig 1 . In contrast, none of the patients with SSc nor the controls showed positive staining for LMP1.

CLINICAL CHARACTERISTICS OF LMP1 POSITIVE PATIENTS

To investigate the clinical influence of LMP1 positivity we carried out a further analysis. Table 2 summarises the clinical characteristics of LMP1 positive and LMP1 negative IPF patients and shows that there was no difference in clinical features at the initial examination between the two groups.

Follow up periods were similar for LMP1 positive and LMP1 negative patients. Eleven of the 29 patients were treated with oral prednisolone after lung biopsy and the remainder 


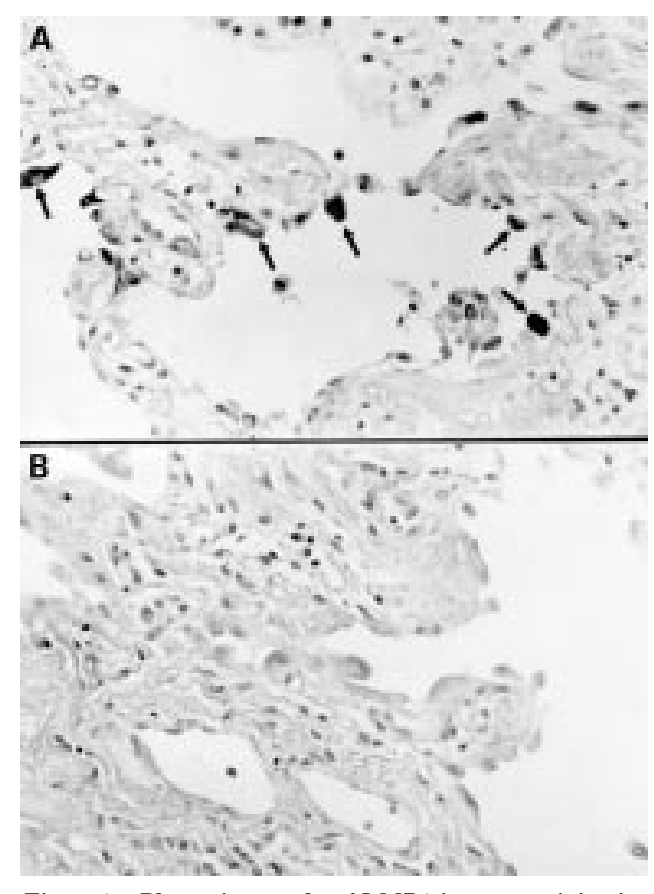

Figure 1 Photomicrographs of LMP1 immunostaining in lung tissue from a patient with IPF (methyl green; original magnification $\times 160$ ). (A) Staining with anti-LMP1 antibody. The cuboidal epithelial cells show positive staining (arrows). (B) Control staining.

did not receive treatment because they were clinically stable. The use of systemic steroids after lung biopsy was more frequent in LMP1 positive patients than in LMP1 negative patients $(\mathrm{p}<0.05)$. Ten patients died during the follow up period. Causes of death included respiratory failure $(n=5)$, lung cancer $(n=3)$, respiratory infection $(n=1)$, and heart failure $(n=1)$. Death from respiratory failure was significantly higher in LMP1 positive patients than in LMP1 negative patients (4 of $9(44 \%)$ versus 1 of $20(5 \%), p=0.022, O R=15.20$, $95 \%$ CI 1.3 to 168.0 ).

Table 2 Comparison of clinical characteristics between LMP1 positive and LMP1 negative patients with IPF

\begin{tabular}{|c|c|c|c|}
\hline & $L M P 1+(n=9)$ & $L M P 1-(n=20)$ & $p$ value \\
\hline Mean (range) age (years) & $56(38-63)$ & $60(47-72)$ & NS \\
\hline $\operatorname{Sex}(M / F)$ & $6 / 3$ & $16 / 4$ & NS \\
\hline Smoking history & 6 & 15 & NS \\
\hline Dyspnoea score & $5.8(4.2)$ & $4.8(4.1)$ & NS \\
\hline Clubbing & 6 & 12 & NS \\
\hline Radiographic score & $5.5(1.0)$ & $4.9(1.2)$ & NS \\
\hline \multicolumn{4}{|l|}{ Laboratory findings at initial examination: } \\
\hline LDH (IU/1) & $251(101)$ & $279(118)$ & NS \\
\hline $\mathrm{CRP}(\mathrm{mg} / \mathrm{dl})$ & $0.2(0.2)$ & $0.5(0.7)$ & NS \\
\hline $\mathrm{PaO}_{2}(\mathrm{kPa})$ & $11.0(0.9)$ & $11.0(1.5)$ & NS \\
\hline$\% \mathrm{VC}(\%)$ & $73.6(33.4)$ & $79.9(19.7)$ & NS \\
\hline \multicolumn{4}{|l|}{ Bronchoalveolar lavage cells (\%) } \\
\hline Macrophages & $91.0(10.0)$ & $82.5(24.2)$ & NS \\
\hline Lymphocytes & $4.7(7.5)$ & $13.0(23.7)$ & NS \\
\hline Neutrophils & $6.6(3.5)$ & $5.8(4.3)$ & NS \\
\hline Eosinophils & $0.5(1.0)$ & $1.9(4.2)$ & NS \\
\hline Mean (range) follow up period (mo) & $42(12-105)$ & $41(3-98)$ & NS \\
\hline Steroid treatment & $6(67 \%)$ & $5(25 \%)$ & $<0.05$ \\
\hline \multicolumn{4}{|l|}{ Outcome } \\
\hline Died & $5(55 \%)$ & $5(25 \%)$ & NS \\
\hline \multicolumn{4}{|l|}{ Cause of death } \\
\hline Respiratory failure & $4(44 \%)$ & $1(5 \%)$ & $<0.05$ \\
\hline Lung cancer & $1(11 \%)$ & $2(10 \%)$ & NS \\
\hline Pulmonary infection & 0 & $1(5 \%)$ & NS \\
\hline Heart failure & 0 & $1(5 \%)$ & NS \\
\hline
\end{tabular}

$\mathrm{LDH}=$ lactate dehydrogenase $\mathrm{CRP}=\mathrm{C}$ reactive protein $; \mathrm{PaO}_{2}=$ arterial oxygen tension $; \mathrm{VC}=$ vital capacity.

Values are expressed as mean (SD) unless otherwise indicated.
In a follow up study of the patients with SSc all received D-penicillamine after the lung biopsy and none of them died of pulmonary fibrosis during the study period.

\section{Discussion}

This study found EBV DNA in the lungs of patients with IPF as well as controls. Only two reports investigating whether EBV DNA is present in lung tissue from IPF patients have been previously published. ${ }^{56}$ Wangoo et $a l^{6}$ failed to detect EBV DNA by PCR while Stewart et a $\bar{l}$ successfully detected it. Different subjects and the use of different PCR procedures may be responsible for the discrepancy between these results and those found in our study. Like Stewart et al, we included an internal amplification control to ensure DNA extraction from paraffin blocks whereas Wangoo et al did not. In addition, Wangoo et al used a single step PCR method whereas we, like Stewart et al, used a two step PCR procedure to obtain higher sensitivity. We believe that EBV DNA can be detected in the lungs because of its ubiquitous nature, as suggested by Lung et $a l .{ }^{18}$

Our data also indicated that the prevalence of EBV DNA was significantly higher in the affected lungs of IPF patients than in normal lung tissue from control subjects. This finding agreed with the previous data by Stewart et al who speculated that EBV might be involved in the pathogenesis of the disease. Although the role of EBV remains to be further clarified, it should be noted that EBV has been detected more frequently in several chronic pathological tissues than in the corresponding normal tissues, including synovial tissue in rheumatoid arthritis, ${ }^{19}$ salivary glands in Sjögren's syndrome, ${ }^{20}$ and the lungs in lymphocytic interstitial pneumonia ${ }^{21}$ or rapidly progressive interstitial pneumonitis associated with polymyositis/dermatomyositis. ${ }^{17}$ These findings may collectively indicate that chronic inflammatory states are associated with an increase in the detection of this virus.

We found that LMP1 was positive in the cuboidal epithelial cells of the lungs from some patients with IPF, and that its positivity was significantly correlated with disease progression to respiratory failure. In contrast, neither the patients with SSc nor the control subjects showed positive results for LMP1 staining, and it was noted that the clinical course of the patients with SSc was quite stable during follow up. These results suggest that LMP1 expression by pulmonary epithelial cells infected with EBV leads to acceleration of lung inflammation and results in a poor clinical outcome in IPF. Although the mechanism underlying LMP1 expression by EBV infected cells in some patients with IPF remains uncertain, it is tempting to speculate possible explanations for our observation based on recent publications on LMP1. For example, LMP1 expression was reported to inhibit human epithelial cell differentiation, ${ }^{11}$ to suppress $\mathrm{p} 53$ mediated apoptosis, ${ }^{22}$ and to upregulate HLA-DR ${ }^{23}$ and ICAM-1 expression ${ }^{24}$ in transfected cells, 
which could possibly cause an alteration in the inflammatory response as well as impairment of tissue repair, resulting in fibrosis.

LMP1 staining was found to be indicative of disease activity and may be a useful finding for the management of IPF in which there is considerable heterogeneity in disease progression. Previously reported parameters for such clinical evaluation have included serum levels of lactate dehydrogenase $(\mathrm{LDH}),{ }^{25} \mathrm{KL}-6,{ }^{26}$ and circulating immune complexes, ${ }^{27}$ the lymphocyte ${ }^{28}$ or eosinophil ${ }^{29}$ count in bronchoalveolar lavage fluid, and histological evaluation for cellularity and fibrosis. ${ }^{2}{ }^{30}$ As well as these parameters, LMP1 staining may indicate, to some degree, the disease activity or disease progression, although the sensitivity and accuracy of these remain to be further established.

In conclusion, using PCR we have detected EBV DNA in the lungs of patients with IPF as well as in those with SSc and control subjects, and we have shown that LMP1 positivity, measured by immunohistochemistry, is related to the prognosis of IPF. These results raise critical issues which need to be further investigated, such as the mechanism by which EBV produces LMP1 protein in some IPF patients and how this protein alters the function of cells in the lungs.

1 Crystal RG, Fulmer JD, Roberts WC, et al. Idiopathic pulmonary fibrosis. Clinical, histologic, radiographic, physiand biochemical aspects. Ann Intern Med 1974;85:769-88.

2 Carrington CB, Gaensler EA, Coutu RE, et al. Natural history and treated course of usual and desquamative interstitial pneumonia. N Engl f Med 1978;298:801-9.

3 Vergnon JM, Vincent M, De The G, et al. Cryptogenic Vergnon JM, Vincent M, De The G, et al. Cryptogenic
fibrosing alveolitis and Epstein-Barr virus: an association? fibrosing alveolitis and

4 Egan JJ, Stewart JP, Hasleton PS, et al. Epstein-Barr virus replication within pulmonary epithelial cells in cryptogenic fibrosing alveolitis. Thorax 1995;50:1234-9.

5 Stewart JP, Egan JJ, Ross AJ, et al. The detection of EpsteinBarr virus DNA in lung tissue from patients with idiopathic pulmonary fibrosis. Am f Respir Crit Care Med 1999;159: 1336-41

6 Wangoo AR, Shaw J, Diss TC, et al. Cryptogenic fibrosing alveolitis: lack of association with Epstein-Barr virus infection. Thorax 1997;52:888-91.

7 Liebowitz D, Wang D, Kieff E. Orientation and patching the latent infection membrane protein encoded by EpsteinBarr virus. F Virol 1986;58:233-7.

8 Gilligan K, Rajadurai P, Resnick L, et al. Epstein-Barr virus small nuclear RNAs are not expressed in permissively infected cells in AIDS-associated leukoplakia. Proc Nat Acad Sci USA 1990;87:8790-4.

9 Kaye K, Izumi KM, Kieff E. Epstein-Barr virus latent memKaye K, Izumi KM, Kieff E. Epstein-Barr virus latent mem-
brane protein 1 is essential for B-lymphocyte growth transbrane protein 1 is essential for B-lymphocyte growth tran
formation. Proc Natl Acad Sci USA 1993;90:9150-94.

10 Wang D, Liebowitz D, Kieff E. An EBV membrane protein expressed in immortalized lymphocytes transforms established rodent cells. Cell 1985;43:831-40.
11 Dawson CW, Rickinson AB, Young LS. Epstein-Barr virus latent membrane protein inhibits human epithelial cell differentiation. Nature 1990;344:777-80.

12 Fahraeus R, Rymo L, Rhim JS, et al. Morphological transformation of human keratinocytes expressing the LMP-1 gene of Epstein-Barr virus. Nature 1990;345:4479.

13 Tung KT, Wells AU, Rubens MB, et al. Accuracy of the typical computed tomographic appearances of fibrosing alveolitis. Thorax 1993;48:334-8.

14 Waters LC, King TE, Schwarz MI, et al. A clinical, radiologic and physiologic scoring system for the longitudinal assessment of patients with idiopathic pulmonary fibrosis. Am Rev Respir Dis 1986;133:97-103.

15 American Rheumatism Association. Preliminary criteria for the classification of systemic sclerosis (scleroderma): report of the Subcommittee for Scleroderma Criteria of the American Rheumatism Association Diagnostic and Therapeutic Criteria Committee. Arthritis Rheum 1980;23:58190.

16 Hashimoto Y, Nawata Y, Kurasawa K, et al. Investigation of EB virus and cytomegalovirus in rapidly progressive interstitial pneumonitis in polymyositis/dermatomyositis by in situ hybridization and polymerase chain reaction. Clin Immunol Immunopathol 1995;77:298-306.

17 Saiki RK, Gelfand DH, Stoffel S, et al. Primer-directed enzymatic amplification of DNA with a thermostable DNA polymerase. Science 1988;239:487-91.

18 Lung ML, Lam WK, So SY, et al. Evidence that respiratory tract is major reservoir for Epstein-Barr virus. Lancet 1985; i:889-92.

19 Takei M, Mitamura K, Fujiwara S, et al. Detection of Epstein-Barr virus-encoded small RNA 1 and latent membrane protein 1 in synovial lining cells from rheumatoid brane protein 1 in synovial lining cells from rhe

20 Wen S, Shimizu N, Yoshiyama H, et al. Association of Epstein-Barr virus (EBV) with Sjögren's syndrome. Differential EBV expression between epithelial cells and lymphocytes in salivary glands. Am f Pathol 1996;149: 1511-7.

21 Andiman WA, Martin K, Rubinstein A, et al. Opportunistic lymphoproliferations associated with Epstein-Barr viral DNA in infants and children with AIDS. Lancet 1985; ii: 1390-3.

22 Fries KL, Miller WE, Raab-Traub N. Epstein-Barr virus latent membrane protein 1 blocks p53-mediated apoptosis latent membrane protein 1 blocks p53-mediated apoptosis
through the induction of the A20 gene. F Virol 1996;70: 8653-9.

23 Zhang Q,Brooks L, Busson P, et al. Epstein-Barr virus (EBV) latent membrane protein 1 increases HLA class II expression in an EBV-negative B cell line. Eur f Immunol 1994;24:1467-70.

24 Wang D, Liebowitz D, Wang F, et al. Epstein-Barr virus latent infection membrane protein alters the human B-lymphocyte phenotype: deletion of the amino terminus abolishes activity. F Virol 1988;62:4173-84.

25 Matusiewicz SP, Williamson IJ, Sime PJ, et al. Plasma lactate dehydrogenase: a marker of disease activity in cryptogenic fibrosing alveolitis and extrinsic allergic alveolitis? Eur Respir ₹ 1993;6:1282-6.

26 Kobayashi J, Kitamura S. KL-6: a serum marker for interstitial pneumonia. Chest 1995;108:311-5.

27 Dreisin RB, Schwarz MI, Theofilopoulos AN, et al. Circulating immune complexes in the idiopathic interstitial pneumonias. N Engl f Med 1978;298:353-7.

28 Watters LC, Schwarz MI, Cherniack RM, et al. Idiopathic pulmonary fibrosis. Pretreatment bronchoalveolar lavage cellular constituents and their relationships with lung histopathology and clinical response to therapy. Am Rev Respir Dis 1987;135:696-704.

29 Peterson MW, Monick M, Hunninghake GW. Prognostic role of eosinophils in pulmonary fibrosis. Chest 1987;92: 51-6.

30 Crystal RG, Bitterman PB, Rennard SI, et al. Interstitial lung disease of unknown cause. Part II. $N$ Engl $f$ Med 1984;310:235-44. 